TITLE:

\title{
NASICON vs. Na metal: a new counter electrode to evaluate electrodes for Na secondary batteries
}

\section{$\operatorname{AUTHOR}(S)$ :}

Hwang, Jinkwang; Takeuchi, Koki; Matsumoto, Kazuhiko; Hagiwara, Rika

\section{CITATION:}

Hwang, Jinkwang ... [et al]. NASICON vs. Na metal: a new counter electrode to evaluate electrodes for Na secondary batteries. Journal of Materials Chemistry A 2019, 7(47): 2705727065

ISSUE DATE:

2019-12-21

URL:

http://hdl.handle.net/2433/245039

\section{RIGHT:}

(C) The Royal Society of Chemistry 2019; The full-text file will be made open to the public on 17 August 2020 in accordance with publisher's 'Terms and Conditions for Self-

Archiving'.; This is not the published version. Please cite only the published version.; この 論文は出版社版でありません。引用の際には出版社版をご確認ご利用ください。 


\title{
Journal Name
}

\section{ARTICLE}

\section{NASICON vs. Na Metal: A New Counter Electrode to Evaluate Electrodes for Na Secondary Batteries}

Received 00th January 20xx, Accepted 00th January 20xx

DOI: $10.1039 / \times 0 \times x 00000 x$

www.rsc.org/

\author{
Jinkwang Hwang, ${ }^{a}$ Koki Takeuchi , ${ }^{a}$ Kazuhiko Matsumoto, ${ }^{* a, b}$ Rika Hagiwara ${ }^{a, b}$
}

\begin{abstract}
$\mathrm{Na}$ metal has been used as a counter electrode in half-cell configuration to test positive and negative electrode materials for $\mathrm{Na}$ secondary batteries. However, there are significant obstacles including high reactivity, which generates resistive passivation layer along with electrolyte decomposition, dendrite formation that results in short cyclability, dead Na metal accumulation, which impedes $\mathrm{Na}^{+}$transport, and low melting point, which limits its use below $98{ }^{\circ} \mathrm{C}$. Herein, an alternative counter electrode is devised using NASICON-type $\mathrm{Na}_{3} \mathrm{~V}_{2}\left(\mathrm{PO}_{4}\right)_{3}$ to measure accurate electrochemical behaviour of working electrode material and to use for measurements at above the melting point of Na metal. The novel counter electrode is prepared by mixing $\mathrm{Na}_{3} \mathrm{~V}_{2}\left(\mathrm{PO}_{4}\right)_{3}$ and $\mathrm{NaV}_{2}\left(\mathrm{PO}_{4}\right)_{3}$, and the latter is prepared by the desodiation of $\mathrm{Na}_{3} \mathrm{~V}_{2}\left(\mathrm{PO}_{4}\right)_{3} \mathrm{Using}_{2} \mathrm{Cl}_{2}$ gas. The resulting $\mathrm{Na}_{3} \mathrm{~V}_{2}\left(\mathrm{PO}_{4}\right)_{3}-\mathrm{NaV}_{2}\left(\mathrm{PO}_{4}\right)_{3}$ electrode exhibits a flat plateau at $3.4 \mathrm{~V}$ vs. $\mathrm{Na}^{+} / \mathrm{Na}$ and lower polarization than the $\mathrm{Na}$ metal. Electrochemical behaviours of the $\mathrm{Na}_{2} \mathrm{FeP}_{2} \mathrm{O}_{7}, \mathrm{Na}_{3} \mathrm{~V}_{2}\left(\mathrm{PO}_{4}\right)_{3}$, and $\mathrm{NaCrO}$ electrodes tested with the new counter electrode match the known curves measured with the Na metal at low current densities and show better cyclability and rate performance. Moreover, the electrochemical properties of these electrode materials are verified at a temperature above the melting point of $\mathrm{Na}$ metal for the first time.
\end{abstract}

\section{Introduction}

With the expansion of the applications of secondary batteries, the research in this field is rapidly progressing. Owing to the low cost and high abundance of $\mathrm{Na}$ resources, $\mathrm{Na}$ secondary batteries are a viable alternative to current lithium secondary batteries for large-scale energy storage systems such as in a power grid. ${ }^{1-12}$ Herein, positive and negative electrode materials and electrolytes for Na secondary batteries have been extensively investigated to obtain better performance in terms of high energy and power densities, long cyclability, and high safety. ${ }^{1-14}$

Till date, the electrochemical measurements for $\mathrm{Na}$ secondary batteries typically utilize $\mathrm{Na}$ metal as a counter electrode in a half-cell configuration ( $\mathrm{Na}$ metal is also regarded as a reference electrode at the same time in a two-electrode half-cell configuration) owing to its high capacity and convenience in lab-scale experimental set-up. ${ }^{15-17}$ However, $\mathrm{Na}$

\footnotetext{
a. Graduate School of Energy Science, Kyoto University, Sakyo-ku, Kyoto 606-8501, Japan

b. Unit of Elements Strategy Initiative for Catalysts \& Batteries (ESICB), Kyoto University, Katsura, Kyoto 615-8510, Japan

*Corresponding author: Kazuhiko Matsumoto

E-mail: k-matsumoto@energy.kyoto-u.ac.jp

Tel: +81757534817

Fax: +81757535906

† Electronic supplementary information (ESI) available: Material characterization methods, detailed structure information and crystallographic data of $\mathrm{Na}_{3} \mathrm{~V}_{2}\left(\mathrm{PO}_{4}\right)_{3}$ and $\mathrm{NaV}_{2}\left(\mathrm{PO}_{4}\right)_{3}$, additional electrochemical measurement data and discussion and results.. See DOI: 10.XXXXXXX
}

metal is highly reactive to moisture and air, and therefore, it requires handling under an inert atmosphere as well as storage in mineral oil to prevent oxidation. Furthermore, Na metal electrode inevitably forms $\mathrm{Na}$ dendrites during the deposition/dissolution process that accompanies continuous consumption of electrolyte and a severe volumetric change, which degrades the electrochemical performance during cycles including the instability of solid electrolyte interphase (SEI) layer. ${ }^{15-23}$

Recently, several studies reported the unreliability of a $\mathrm{Na}$ metal counter electrode in the organic carbonate-based electrolytes. ${ }^{15-20,23,24}$ Cycle tests were conducted to verify the use of the $\mathrm{Na}$ metal counter electrode with several carbonate organic electrolytes including $1 \mathrm{~mol} \mathrm{dm}^{-3} \mathrm{Na}\left[\mathrm{PF}_{6}\right]-\mathrm{EC} / \mathrm{DEC}$, $\mathrm{Na}\left[\mathrm{PF}_{6}\right]-\mathrm{EC} / \mathrm{DMC}, \quad \mathrm{Na}\left[\mathrm{ClO}_{4}\right]-\mathrm{EC} / \mathrm{PC}, \quad \mathrm{Na}\left[\mathrm{ClO}_{4}\right]-\mathrm{EC} / \mathrm{EMC}$, and $\mathrm{Na}\left[\mathrm{ClO}_{4}\right]$ PC $\quad(\mathrm{DEC}=$ dimethyl carbonate, $\mathrm{DMC}=$ dimethyl carbonate, $\mathrm{PC}=$ propylene carbonate) each using electrode materials of hard carbon, $\mathrm{Na}_{3} \mathrm{~V}_{2}\left(\mathrm{PO}_{4}\right)_{3}$, and $\mathrm{Li}_{4} \mathrm{Ti}_{5} \mathrm{O}_{12}$ in a half-cell configuration. ${ }^{16-19}$ They pointed out that the $\mathrm{Na}$ metal counter electrode is a factor in the capacity fading in half-cell test for the organic carbonate-based electrolytes. ${ }^{16-19}$ With respect to researches on lithium secondary batteries, $\mathrm{Li}_{4} \mathrm{Ti}_{5} \mathrm{O}_{12}$ and $\mathrm{Li}_{x} \mathrm{Sn}$ were reported as an alternative reference and counter electrode material to obtain more accurate electrochemical impedance spectroscopy and charge-discharge test results instead of Li metal electrode. ${ }^{25-27}$

Furthermore, there are also apparent needs for a novel counter electrode which can be used at elevated temperatures above the melting point of $\mathrm{Na}$ metal $\left(98^{\circ} \mathrm{C}\right)$. Studies using ionic liquid electrolytes suggest that the intermediate-temperature operation dramatically improves the rate and cycling 
(a) Mixed Slurry $\left(\mathrm{Na}_{3} \mathrm{~V}_{2}\left(\mathrm{PO}_{4}\right)_{3}: \mathrm{NaV}_{2}\left(\mathrm{PO}_{4}\right)_{3}: \mathrm{CB}:\right.$ Binder $)$
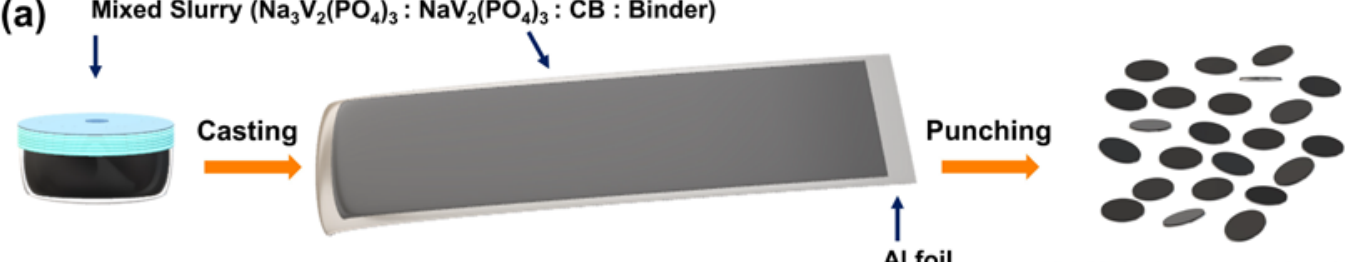

Al foil

$\mathrm{N}_{3} \mathrm{~N}_{1} \mathrm{VP}$ Counter Electrode
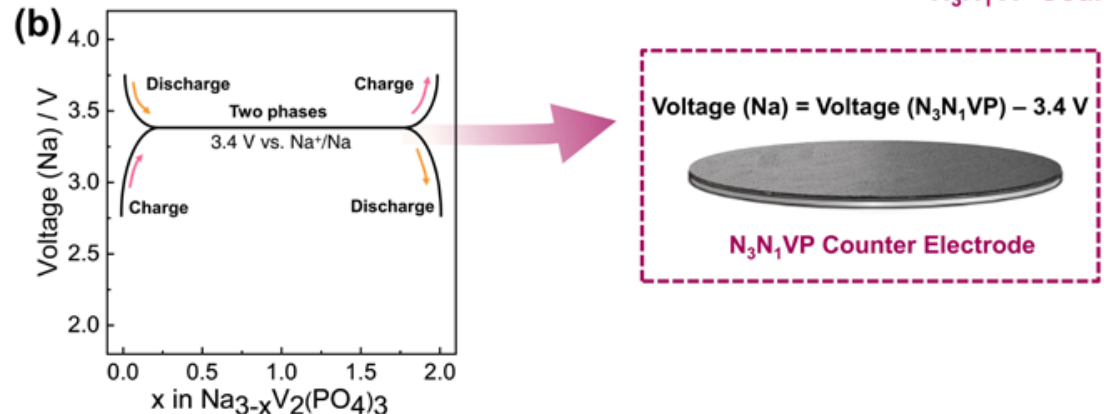

Fig. 1 (a) Schematic of the $\mathrm{N}_{3} \mathrm{~N}_{1} \mathrm{VP}$ counter electrode preparation process and (b) concept of the counter electrode utilizing the sodiation-desodiation plateau of the $\mathrm{Na}_{3} \mathrm{~V}_{2}\left(\mathrm{PO}_{4}\right)_{3}-\mathrm{NaV}_{2}\left(\mathrm{PO}_{4}\right)_{3}$ equilibrium state. $\mathrm{CB}$ denotes carbon black (Super $\mathrm{C} 65$ ).

performance. ${ }^{12,}$, $28-32$ However, the Na metal counter electrode can be used only below its melting point in half-cell configuration, even if electrode materials and electrolytes can be used at high temperatures. ${ }^{13,}$, 28, 33-39

The NASICON-type (NASICON = Na super ionic conductor) $\mathrm{Na}_{3} \mathrm{~V}_{2}\left(\mathrm{PO}_{4}\right)_{3}$ is a well-studied polyanionic positive electrode material for Na secondary batteries. ${ }^{31,32,40-46}$ This material has an open framework with facile $\mathrm{Na}$ ion diffusion paths and high thermal and electrochemical stabilities. Previous studies have revealed that the sodiation-desodiation mechanism between $\mathrm{Na}_{3} \mathrm{~V}_{2}\left(\mathrm{PO}_{4}\right)_{3}$ and $\mathrm{NaV}_{2}\left(\mathrm{PO}_{4}\right)_{3}$ follows the $\mathrm{V}^{3+} / \mathrm{V}^{4+}$ redox reaction with a theoretical capacity of $117 \mathrm{mAh} \mathrm{g}^{-1}$ based on the twoelectron reaction for two $V$ atoms, $31,32,42-47$ providing a flat plateau at $3.4 \mathrm{~V}$ vs. $\mathrm{Na}^{+} / \mathrm{Na}$. A prior study used this redox couple as a counter electrode for $\mathrm{Na}-\mathrm{O}_{2}$ batteries, ${ }^{22}$ where $\mathrm{Na}_{3} \mathrm{~V}_{2}\left(\mathrm{PO}_{4}\right)_{3}$ was electrochemically charged with $\mathrm{Na}$ metal and disassembled and assembled again with a carbon-based $\mathrm{O}_{2}$ cathode for the $\mathrm{Na}-\mathrm{O}_{2}$ cell measurements. ${ }^{22}$

Herein, a new counter electrode of $\mathrm{N}_{3} \mathrm{~N}_{1} \mathrm{VP}$ in the state of $\mathrm{Na}_{3} \mathrm{~V}_{2}\left(\mathrm{PO}_{4}\right)_{3}-\mathrm{Na}_{3} \mathrm{~V}_{2}\left(\mathrm{PO}_{4}\right)_{3}$ two-phase plateau region is proposed for $\mathrm{Na}$ secondary batteries. Fig. 1 schematically shows the concept for the new counter electrode. Electrochemical desodiation procedure of $\mathrm{Na}_{3} \mathrm{~V}_{2}\left(\mathrm{PO}_{4}\right)_{3}$ is possible for this purpose, but it is considerably cumbersome for regular experiments, considering the assembly and disassembly of coin cells, and washing and drying of the electrode if necessary. This bottleneck of the concept has been solved by chemical desodiation of $\mathrm{Na}_{3} \mathrm{~V}_{2}\left(\mathrm{PO}_{4}\right)_{3}$ to $\mathrm{NaV}_{2}\left(\mathrm{PO}_{4}\right)_{3}$ using $\mathrm{Cl}_{2}$ gas in this study, involving the sizeable and convenient production of uniform $\mathrm{NaV}_{2}\left(\mathrm{PO}_{4}\right)_{3}$. We expected the counter electrode could have a state of charge $(\mathrm{SOC})=50 \%$ with an initial potential of 3.4 $\mathrm{V}$ vs. $\mathrm{Na}^{+} / \mathrm{Na}$ by simply mixing $\mathrm{Na}_{3} \mathrm{~V}_{2}\left(\mathrm{PO}_{4}\right)_{3}$ and $\mathrm{NaV}_{2}\left(\mathrm{PO}_{4}\right)_{3}$ in a 1:1 molar ratio and the electrode in the flat plateau region is able to be used for a counter electrode in the half-cell configuration. The electrochemical behaviour is demonstrated using well-studied electrode materials, $\mathrm{Na}_{2} \mathrm{FeP}_{2} \mathrm{O}_{7}, \mathrm{Na}_{3} \mathrm{~V}_{2}\left(\mathrm{PO}_{4}\right)_{3}$, and $\mathrm{NaCrO}_{2}$, with two different types of electrolytes, $1 \mathrm{~mol} \mathrm{dm}^{-}$
$3 \mathrm{Na}\left[\mathrm{PF}_{6}\right]-\mathrm{EC} / \mathrm{DMC}$ (1:1 vol/vol) organic solvent electrolyte (hereafter abbreviated as $\mathrm{OE}$ ) and $40 \mathrm{~mol} \% \mathrm{Na}[\mathrm{FSA}]-$ [ $\left.\mathrm{C}_{2} \mathrm{C}_{1} \mathrm{im}\right][\mathrm{FSA}] \quad\left(\mathrm{C}_{2} \mathrm{C}_{1} \mathrm{im}=1\right.$ 1-ethyl-3-methylimidazolium, $\mathrm{FSA}=$ bis(fluorosulfonyl)amide) ionic liquid electrolyte (hereafter abbreviated as IL). ${ }^{48}$

\section{Experimental}

\section{General procedures and reagents}

All air-sensitive materials were handled under dry $\mathrm{Ar}$ atmosphere in a dry box $\left(\mathrm{H}_{2} \mathrm{O}<1 \mathrm{ppm}, \mathrm{O}_{2}<1 \mathrm{ppm}\right)$. Oxalic acid dihydrate (Wako Pure Chemical Industries, purity: 99.5 100.2\%), $\mathrm{V}_{2} \mathrm{O}_{5}$ (Sigma-Aldrich Chemistry, purity: 99.6\%), $\mathrm{NaOH}$ (Wako Pure Chemical Industries, purity: 97.0\%), $\mathrm{NH}_{4} \mathrm{H}_{2} \mathrm{PO}_{4}$ (Wako Pure Chemical Industries, 99.0\% purity), and glucose (Wako Pure Chemical Industries) were used to prepare precursors of $\mathrm{Na}_{3} \mathrm{~V}_{2}\left(\mathrm{PO}_{4}\right)_{3}$. The powdery carbon-coated $\mathrm{Na}_{3} \mathrm{~V}_{2}\left(\mathrm{PO}_{4}\right)_{3}$ was synthesized via a sol-gel method as previously reported. ${ }^{31}$ A Na metal piece (Sigma-Aldrich Chemistry, 99.95\% purity) was obtained after cutting a Na metal chunk into pieces. The FSA salts, Na[FSA] (Mitsubishi Materials Electronic Chemicals, purity $>99 \%$ ) and $\left[\mathrm{C}_{2} \mathrm{C}_{1}\right.$ im] [FSA] (Kanto Chemical, purity $>99.9 \%$; water content $<30 \mathrm{ppm}$ ) were dried under vacuum for $24 \mathrm{~h}$ at $80^{\circ} \mathrm{C}$. The organic electrolyte, $1 \mathrm{~mol} \mathrm{dm}^{-3}$ of $\mathrm{Na}\left[\mathrm{PF}_{6}\right]-\mathrm{EC} / \mathrm{DMC}$ (1:1 vol/vol; Kishida Chemical Co., Ltd.,), was used as supplied. $\mathrm{Na}_{2} \mathrm{FeP}_{2} \mathrm{O}_{7}$ and $\mathrm{NaCrO}_{2}$ samples were prepared in the same manner as previously reported. ${ }^{49}, 50$ Details of analytical methods are summarized in ESIt.

\section{Synthesis of $\mathrm{NaV}_{2}\left(\mathrm{PO}_{4}\right)_{3}$}

The powdery $\mathrm{NaV}_{2}\left(\mathrm{PO}_{4}\right)_{3}$ was prepared by the chemical desodiation of $\mathrm{Na}_{3} \mathrm{~V}_{2}\left(\mathrm{PO}_{4}\right)_{3}$ using $\mathrm{Cl}_{2}$ gas (the reaction line is shown in Fig. 2a). Into an air-tight glass flask $\left(\sim 600 \mathrm{dm}^{3}\right)$ with a metal lid equipped with a metal valve, $6.00 \mathrm{~g}$ of $\mathrm{Na}_{3} \mathrm{~V}_{2}\left(\mathrm{PO}_{4}\right)_{3}$ (11.71 mmol, carbon content: $10.5 \%), 5.33 \mathrm{~g}$ of $\mathrm{AlCl}_{3}(40.00$ $\mathrm{mmol}$ ), and $\sim 50 \mathrm{~mL}$ of acetonitrile were added under dry $\mathrm{Ar}$ 
(a)

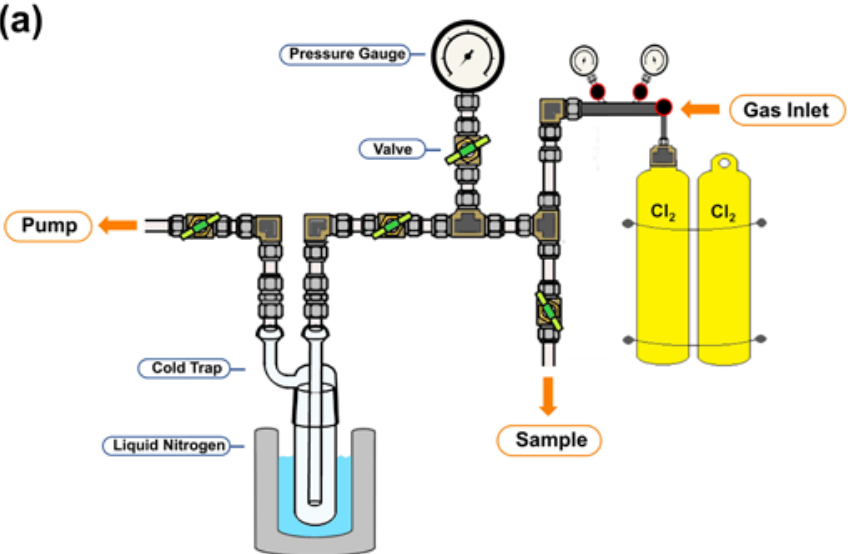

(b)

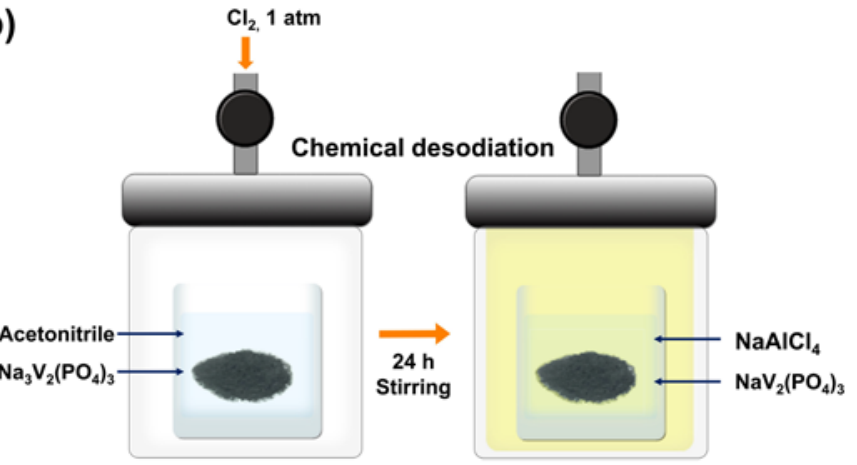

$\mathrm{Na}_{3} \mathrm{~V}_{2}\left(\mathrm{PO}_{4}\right)_{3}+\mathrm{Cl}_{2}+2 \mathrm{AlCl}_{3} \rightarrow \mathrm{NaV}_{2}\left(\mathrm{PO}_{4}\right)_{3}+2 \mathrm{NaAlCl}_{4}$

Fig. 2 Schematic of (a) the reaction line for $\mathrm{Cl}_{2}$ gas supply and (b) the reactor for the preparation of $\mathrm{NaV}_{2}\left(\mathrm{PO}_{4}\right)_{3}$.

atmosphere. The glass flask was connected to the reaction line, and the Ar gas that was inside was removed at $-196{ }^{\circ} \mathrm{C}$. After warming up to room temperature, $1 \mathrm{~atm}$ of $\mathrm{Cl}_{2}$ gas ( $\sim 40 \mathrm{mmol}$ ) was slowly introduced from a storage cylinder into the glass flask. The reaction mixture was agitated for $24 \mathrm{~h}$, and excess $\mathrm{Cl}_{2}$ was pumped off. The final product of $3.75 \mathrm{~g}(8.05 \mathrm{mmol}$, carbon content: $11.8 \%$ ) was obtained by repeated washing with acetonitrile and centrifugation (twice). The product was identified as $\mathrm{NaV}_{2}\left(\mathrm{PO}_{4}\right)_{3}$ by XRD and EDS analysis (Fig. 3).

\section{Coin-cell preparation}

Na metal was cut into a disk ( $10 \mathrm{~mm}$ in diameter), fixed on an $\mathrm{Al}$ plate current collector, and used as a counter electrode. The $\mathrm{N}_{3} \mathrm{~N}_{1} \mathrm{VP}$ counter electrode was prepared by mixing $\mathrm{Na}_{3} \mathrm{~V}_{2}\left(\mathrm{PO}_{4}\right)_{3}$ and $\mathrm{NaV}_{2}\left(\mathrm{PO}_{4}\right)_{3}$ (1:1 molar ratio) with Super $\mathrm{C} 65$ carbon and PVDF (70:25:5 wt\%) in $\mathrm{N}$-methylpyrrolidone using a planetary mixer (AR-100, Thinky, Tokyo, Japan) and pasting the mixture on an Al foil. The mass loading of this electrode was approximately $2 \mathrm{mg}$-active material $\mathrm{cm}^{-2}$ after drying at $80{ }^{\circ} \mathrm{C}$. The $\mathrm{Na}_{3} \mathrm{~V}_{2}\left(\mathrm{PO}_{4}\right)_{3}, \mathrm{Na}_{2} \mathrm{FeP}_{2} \mathrm{O}_{7}$, and $\mathrm{NaCrO}_{2}$ working electrodes were prepared by mixing active materials, carbon black, and PVDF (75:15:10 wt\%) using the planetary mixer. The ratio of the counter and working electrodes was adjusted to 2:1 in theoretical capacity. Coin cells of type-2032 were assembled in an argon-filled glove box (oxygen level $<1 \mathrm{ppm}$ ). The $40 \mathrm{~mol} \%$ $\mathrm{Na}[\mathrm{FSA}]-\left[\mathrm{C}_{2} \mathrm{C}_{1}\right.$ im] $[\mathrm{FSA}]$ ionic liquid electrolyte was prepared by mixing two salts in the target ratio and further dried under vacuum for $24 \mathrm{~h}$ at $80^{\circ} \mathrm{C}$. A glass microfiber (Whatman GF/D) was used as a separator. C-rate current densities were applied based on the theoretical capacity of the working electrode materials $\left(1 \mathrm{C}=97,117\right.$, and $125 \mathrm{~mA} \mathrm{~g}^{-1}$ for $\mathrm{Na}_{2} \mathrm{FeP}_{2} \mathrm{O}_{7}, 51$ $\mathrm{Na}_{3} \mathrm{~V}_{2}\left(\mathrm{PO}_{4}\right)_{3},{ }^{52}$ and $\mathrm{NaCrO}_{2},{ }^{53}$ respectively).

\section{Results and discussion}

\section{Chemical desodiation using $\mathrm{Cl}_{2}$ gas and material characterization}

The flat plateau at $3.4 \mathrm{~V} \mathrm{vs.} \mathrm{Na}^{+} / \mathrm{Na}$ is observed in the $\mathrm{SOC}$ range between $\sim 15 \%$ and $\sim 85 \%$, with the capacity range of approximately 1.5 equivalent of $\mathrm{Na}$ that is reversibly (de)sodiated in the $\mathrm{Na}_{3} \mathrm{~V}_{2}\left(\mathrm{PO}_{4}\right)_{3} / \mathrm{NaV}_{2}\left(\mathrm{PO}_{4}\right)_{3}$ electrode based on the $\mathrm{V}^{4+} / \mathrm{V}^{3}$ redox couple. ${ }^{40} \mathrm{~A}$ schematic of the preparation process of $\mathrm{NaV}_{2}\left(\mathrm{PO}_{4}\right)_{3}$ is depicted in Fig. 2b. $\mathrm{Na}_{3} \mathrm{~V}_{2}\left(\mathrm{PO}_{4}\right)_{3}$ prepared by a sol-gel method ${ }^{31}$ is suspended and desodiated in acetonitrile with $\mathrm{Cl}_{2}$ gas in the presence of $\mathrm{AlCl}_{3}$, based on Equation (1):

$$
\mathrm{Na}_{3} \mathrm{~V}_{2}\left(\mathrm{PO}_{4}\right)_{3}+\mathrm{Cl}_{2}+2 \mathrm{AlCl}_{3} \rightarrow \mathrm{NaV}_{2}\left(\mathrm{PO}_{4}\right)_{3}+2 \mathrm{NaAlCl}_{4}
$$

In this reaction, $\mathrm{Cl}_{2}$ acts an oxidizing agent $\left(4.07 \mathrm{~V}\right.$ vs. $\mathrm{Na}^{+} / \mathrm{Na}$ or $1.36 \mathrm{~V}$ vs. SHE, based on the potential in the aqueous systems), ${ }^{54}$ and $\mathrm{AlCl}_{3}$ acts as a Lewis acid to dissolve $\mathrm{NaCl}$ formed on the surface of $\mathrm{Na}_{3} \mathrm{~V}_{2}\left(\mathrm{PO}_{4}\right)_{3}$. The reaction does not proceed to completion without $\mathrm{AlCl}_{3}$ because of the low solubility of $\mathrm{NaCl}$ into acetonitrile. The obtained $\mathrm{NaV}_{2}\left(\mathrm{PO}_{4}\right)_{3}$ is insoluble in acetonitrile and simply isolated by centrifugation or filtration. A previous report by Gopalakrishnan and Rangan stated that the bubbling of $\mathrm{Cl}_{2}$ gas into $\mathrm{Na}_{3} \mathrm{~V}_{2}\left(\mathrm{PO}_{4}\right)_{3}$ in $\mathrm{CHCl}_{3}$ could fully deintercalate $\mathrm{Na}$ from $\mathrm{Na}_{3} \mathrm{~V}_{2}\left(\mathrm{PO}_{4}\right)_{3}$ and provide $\mathrm{V}_{2}\left(\mathrm{PO}_{4}\right)_{3} .55$ The present method is milder than that reported by Gopalakrishnan and Rangan, and selectively produces $\mathrm{NaV}_{2}\left(\mathrm{PO}_{4}\right)_{3}$ without further oxidation.

Fig. 3 shows the X-ray diffraction (XRD) patterns and scanning electron microscopy (SEM) images with energy
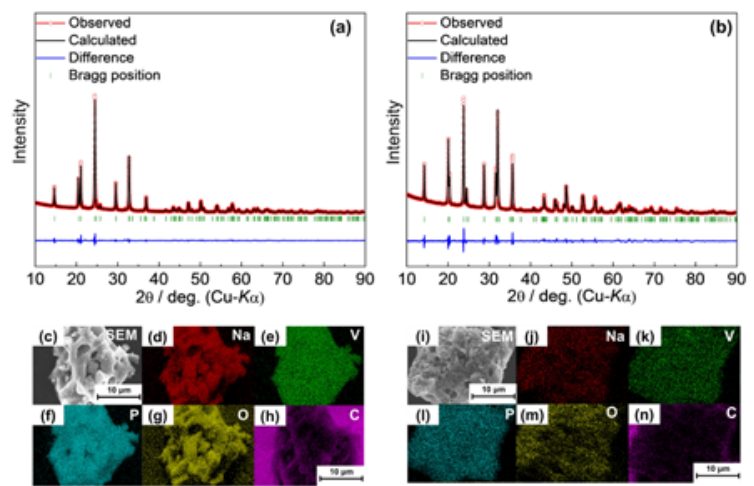

Fig. 3 XRD patterns with Rietveld refinement results for (a) $\mathrm{Na}_{3} \mathrm{~V}_{2}\left(\mathrm{PO}_{4}\right)_{3}$ prepared by a sol-gel method and b) $\mathrm{NaV}_{2}\left(\mathrm{PO}_{4}\right)_{3}$ prepared by chemical desodiation of $\mathrm{Na}_{3} \mathrm{~V}_{2}\left(\mathrm{PO}_{4}\right)_{3}$ with $\mathrm{Cl}_{2}$ gas. SEM images and EDS mappings of (c-h) $\mathrm{Na}_{3} \mathrm{~V}_{2}\left(\mathrm{PO}_{4}\right)_{3}$ and $(\mathrm{i}-\mathrm{n}) \mathrm{NaV}_{2}\left(\mathrm{PO}_{4}\right)_{3}$ 

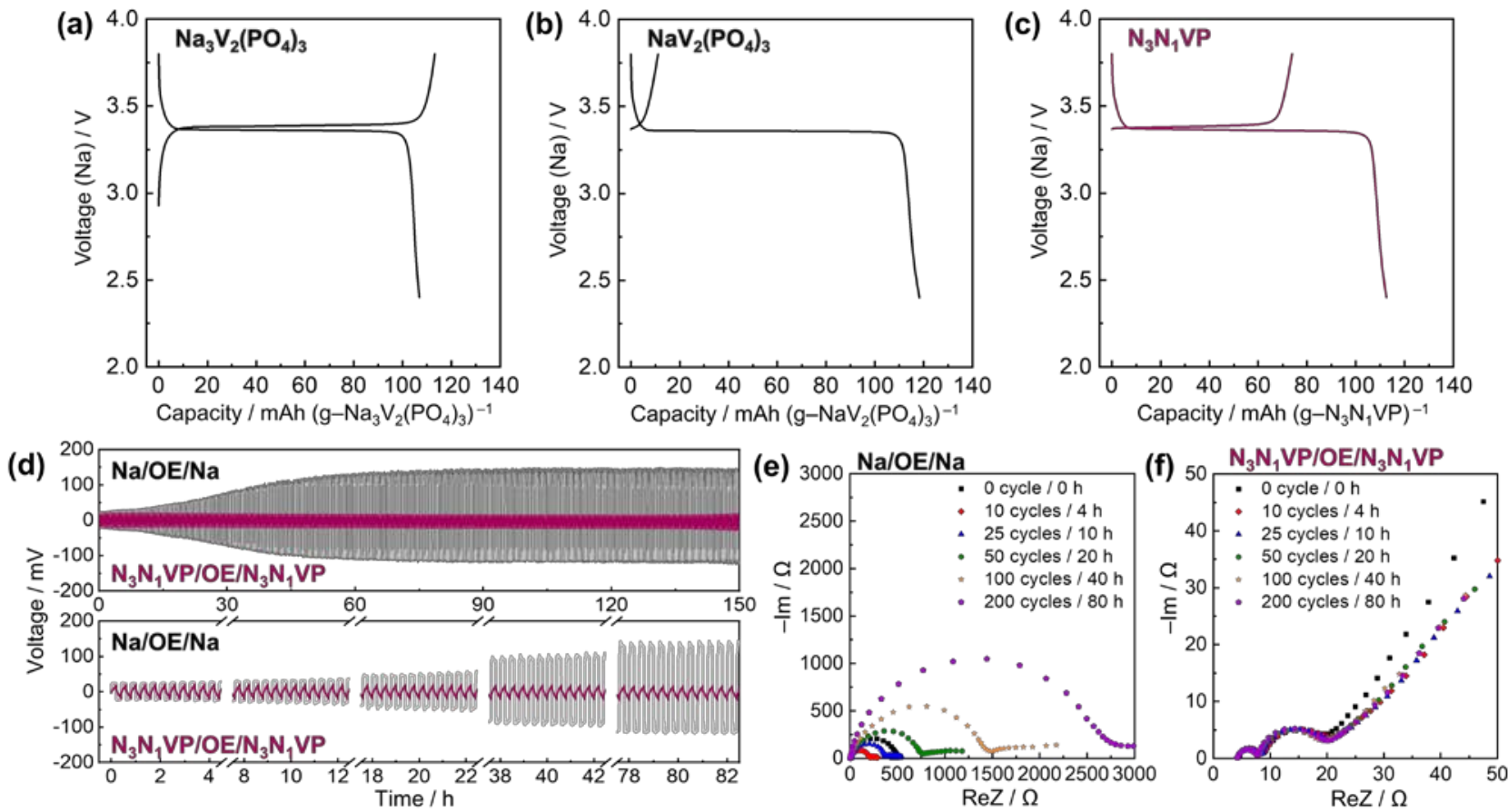

Fig. 4 Charge-discharge curves of the (a) Na/IL/Na $\mathrm{V}_{2}\left(\mathrm{PO}_{4}\right)_{3}$, (b) $\mathrm{Na} / \mathrm{IL} / \mathrm{NaV}_{2}\left(\mathrm{PO}_{4}\right)_{3}$, and (c) $\mathrm{Na} / \mathrm{IL} / \mathrm{N}_{3} \mathrm{~N}_{1} \mathrm{VP}$ cells at $90{ }^{\circ} \mathrm{C}$. Voltage (Na) is the voltage of the cell with Na metal counter electrode. C-rate: $1 \mathrm{C}$. Cutoff voltage: $2.4 / 3.8 \mathrm{~V}$. Voltage profiles of (d) symmetric $\mathrm{Na} / \mathrm{OE} / \mathrm{Na}$ and $\mathrm{N}_{3} \mathrm{~N}_{1} \mathrm{VP} / \mathrm{OE} / \mathrm{N}_{3} \mathrm{~N}_{1} \mathrm{VP}$ cells during cycling test at $25^{\circ} \mathrm{C}$ ( $\mathrm{Na}$ metal stripping-plating for the $\mathrm{Na} / \mathrm{Na}$ cell and $\mathrm{Na}^{+}$desertion-insertion for the $\mathrm{N}_{3} \mathrm{~N}_{1} \mathrm{VP} / \mathrm{N}_{3} \mathrm{~N}_{1} \mathrm{VP}$ cell) at a current density of $0.1 \mathrm{~mA} \mathrm{~cm}^{-2}$ (24 min per cycle). Nyquist plots of the (e) $\mathrm{Na} / \mathrm{OE} / \mathrm{Na}$ and (f) $\mathrm{N}_{3} \mathrm{~N}_{1} \mathrm{VP} / \mathrm{OE} / \mathrm{N}_{3} \mathrm{~N}_{1} \mathrm{VP}$ symmetric cells during the cycles. Frequency range: $10 \mathrm{mHz}-100 \mathrm{kHz}$.

dispersive $\mathrm{X}$-ray spectroscopy (EDS) mappings of $\mathrm{Na}_{3} \mathrm{~V}_{2}\left(\mathrm{PO}_{4}\right)_{3}$

and $\mathrm{NaV}_{2}\left(\mathrm{PO}_{4}\right)_{3}$ prepared in this study. The collected patterns were fitted with the pure $\mathrm{Na}_{3} \mathrm{~V}_{2}\left(\mathrm{PO}_{4}\right)_{3}$ and $\mathrm{NaV}_{2}\left(\mathrm{PO}_{4}\right)_{3}$ phases under the $R \overline{3} c$ space group via the Rietveld refinement (Fig. 3a,b). The lattice parameters of $\mathrm{Na}_{3} \mathrm{~V}_{2}\left(\mathrm{PO}_{4}\right)_{3}(a=8.7305(1)$ $\AA$ and $c=21.858(4) \AA$ with $R_{\mathrm{wp}}=11.1 \%$, Table S1, ESIt) and $\mathrm{NaV}_{2}\left(\mathrm{PO}_{4}\right)_{3}\left(a=8.4335(5) \AA\right.$ and $c=21.543(1) \AA$ with $R_{\mathrm{wp}}=10.6 \%$, Table S2, ESIt) are consistent with the crystallographic data reported in literature ${ }^{41,44}$ (Fig. S1 and Fig. S2 in the ESIt include the refined crystal structures of $\mathrm{Na}_{3} \mathrm{~V}_{2}\left(\mathrm{PO}_{4}\right)_{3}$ and $\mathrm{NaV}_{2}\left(\mathrm{PO}_{4}\right)_{3}$, respectively). These crystallographic data and microscopic images confirm that $\mathrm{Cl}_{2}$ can desodiate $\mathrm{Na}_{3} \mathrm{~V}_{2}\left(\mathrm{PO}_{4}\right)_{3}$ to $\mathrm{NaV}_{2}\left(\mathrm{PO}_{4}\right)_{3}$ without forming impurities, preserving the initial morphology and carbon coating (Fig. 3c,i). The EDS mapping results in Fig. 3d-h and 3j-n verify that all elements are evenly distributed in the prepared particles. The observed element compositions match the theoretical compositions of $\mathrm{Na}_{3} \mathrm{~V}_{2}\left(\mathrm{PO}_{4}\right)_{3}$ and $\mathrm{NaV}_{2}\left(\mathrm{PO}_{4}\right)_{3}$ samples (Table S3, ESI ${ }^{\dagger}$ ).

\section{Electrochemical behaviour of $\mathrm{Na}_{3} \mathrm{~V}_{2}\left(\mathrm{PO}_{4}\right)_{3}, \mathrm{NaV}_{2}\left(\mathrm{PO}_{4}\right)_{3}$, and $\mathrm{N}_{3} \mathrm{~N}_{1} \mathrm{VP}$}

Electrochemical behaviour of $\mathrm{Na}_{3} \mathrm{~V}_{2}\left(\mathrm{PO}_{4}\right)_{3}, \mathrm{NaV}_{2}\left(\mathrm{PO}_{4}\right)_{3}$, and $\mathrm{N}_{3} \mathrm{~N}_{1} \mathrm{VP}$ were separately measured with the $\mathrm{Na}$ metal counter electrode in a half-cell configuration to confirm their basic electrochemical performance. The $\mathrm{N}_{3} \mathrm{~N}_{1} \mathrm{VP}$ counter electrode for coin cell tests was obtained by pasting the slurry of the equimolar mixture of $\mathrm{Na}_{3} \mathrm{~V}_{2}\left(\mathrm{PO}_{4}\right)_{3}$ and $\mathrm{NaV}_{2}\left(\mathrm{PO}_{4}\right)_{3}$ by a mortar and pestle on $\mathrm{Al}$ foil, followed by drying and punching into a disc shape (Fig. 1a). The mixing ratio of $\mathrm{Na}_{3} \mathrm{~V}_{2}\left(\mathrm{PO}_{4}\right)_{3}$ and $\mathrm{NaV}_{2}\left(\mathrm{PO}_{4}\right)_{3}$ could be adjusted depending on the $\mathrm{SOC}$ of the working electrode materials. Herein, the 1:1 molar ratio was used for versatile applications because it could respond to both the sodiation-starting or desodiation-starting working electrodes.

Fig. 4 shows the charge-discharge curves of the $\mathrm{Na} / \mathrm{IL} / \mathrm{Na}_{3} \mathrm{~V}_{2}\left(\mathrm{PO}_{4}\right)_{3}, \mathrm{Na} / \mathrm{IL} / \mathrm{NaV}_{2}\left(\mathrm{PO}_{4}\right)_{3}$, and $\mathrm{Na} / \mathrm{IL} / \mathrm{N}_{3} \mathrm{~N}_{1} \mathrm{VP}$ cells at $90{ }^{\circ} \mathrm{C}$ and cycle tests with electrochemical impedance spectroscopy (EIS) results for the $\mathrm{Na} / \mathrm{Na}$ and $\mathrm{N}_{3} \mathrm{~N}_{1} \mathrm{VP} / \mathrm{N}_{3} \mathrm{~N}_{1} \mathrm{VP}$ symmetric cells with $\mathrm{OE}$ and IL at selected cycles. The chargedischarge tests were carried out with IL at $90{ }^{\circ} \mathrm{C}$ because IL provided more stable electrochemical properties in the half-cell test with Na metal electrode than those with organic electrolyte particularly during the initial cycles, and the elevated temperature minimized the large polarization of $\mathrm{Na}$ metal observed at $25^{\circ} \mathrm{C}$. The initial charge curve of $\mathrm{Na}_{3} \mathrm{~V}_{2}\left(\mathrm{PO}_{4}\right)_{3}$ starts from the reduced state, and the charge and discharge capacities are almost the same (Fig. 4a). Contrarily, for $\mathrm{NaV}_{2}\left(\mathrm{PO}_{4}\right)_{3}$, the initial charge curve starts at $3.4 \mathrm{~V}$ vs. $\mathrm{Na}^{+} / \mathrm{Na}$ with a charge capacity of $11 \mathrm{mAh} \mathrm{g}^{-1}$. There are two possible factors for this capacity: the partial reduction of $\mathrm{NaV}_{2}\left(\mathrm{PO}_{4}\right)_{3}$ by carbon black or impurities during electrode fabrication and the formation of cathode electrolyte interphase in contact with the electrolyte (Fig. $4 \mathrm{~b}$ ). $\mathrm{N}_{3} \mathrm{~N}_{1} \mathrm{VP}$ has a resting potential of $3.4 \mathrm{~V}$ vs. $\mathrm{Na}^{+} / \mathrm{Na}$ and exhibits initial charge and discharge capacities of 73 and 112 $\mathrm{mAh} \mathrm{g}^{-1}$ (Fig. 4c), respectively. This result demonstrates that the adjust amount of $\mathrm{Na}_{3} \mathrm{~V}_{2}\left(\mathrm{PO}_{4}\right)_{3}$ and $\mathrm{NaV}_{2}\left(\mathrm{PO}_{4}\right)_{3}$ can adjust the apparent SOC of this electrode material from the initial state, and both are acted as active materials are involved during the initial charge and discharge processes, providing the plateau region which can be used as a standard potential of the counter electrode as depicted in Fig. 1b. Furthermore, the $\mathrm{Cl}_{2}$ 
(a)

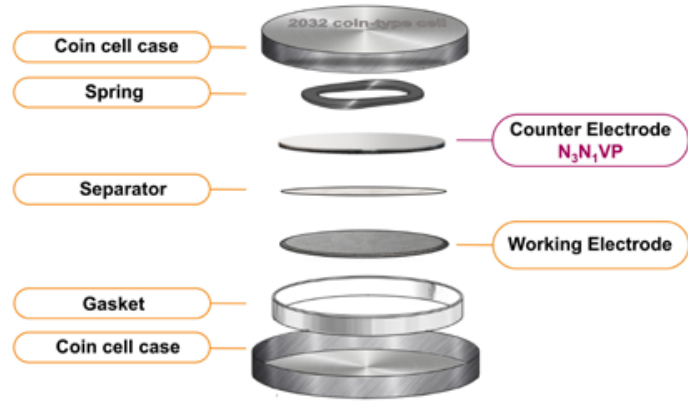

(b)

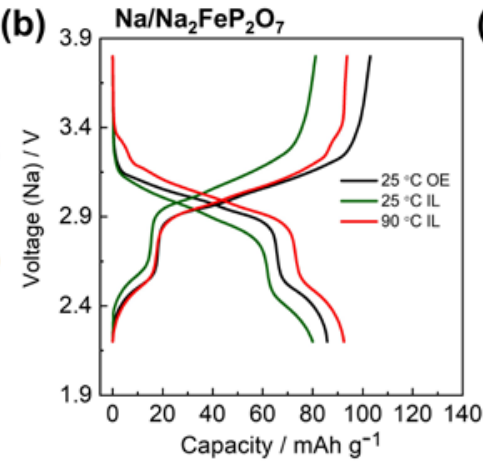

(c) $\mathrm{N}_{3} \mathrm{~N}_{1} \mathrm{VP} / \mathrm{Na}_{2} \mathrm{FeP}_{2} \mathrm{O}_{7}$

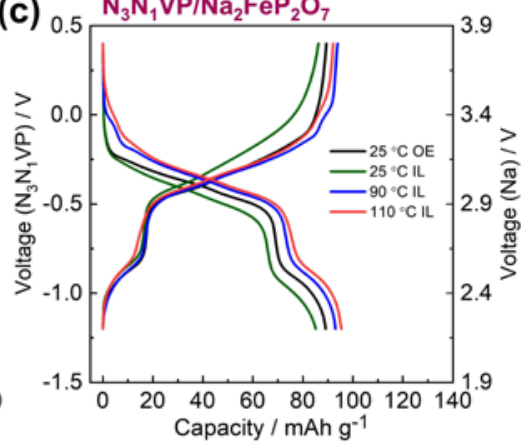

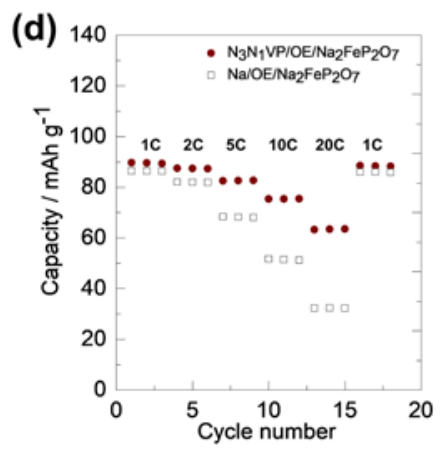
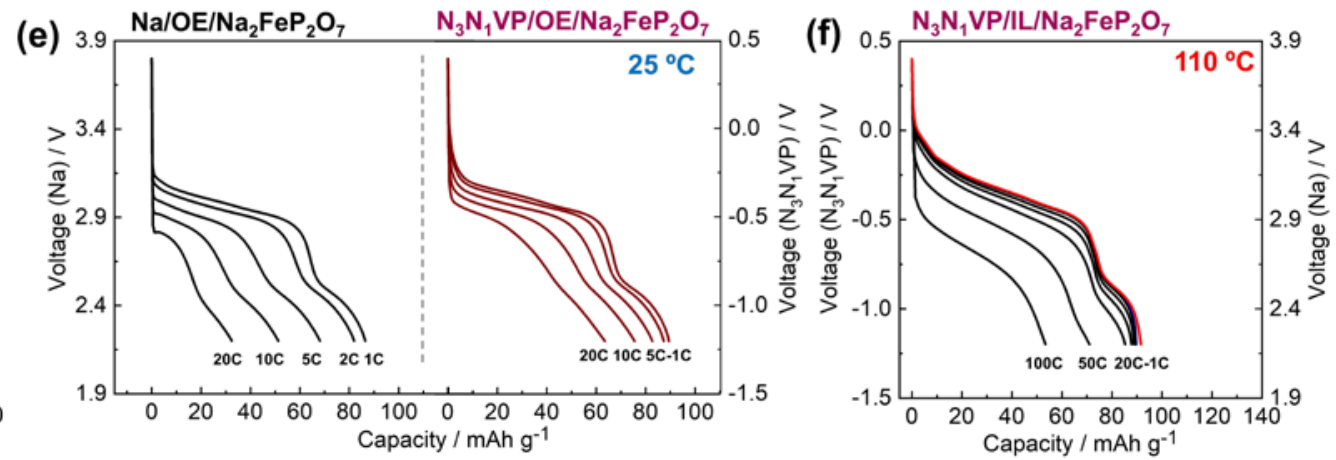

Fig. 5 (a) Schematic of a coin-cell using the $\mathrm{N}_{3} \mathrm{~N}_{1} \mathrm{VP}$ counter electrode and working electrode of a target material for half-cell tests. Charge-discharge curves of the (b) Na/Na $\mathrm{F}_{2} \mathrm{Fe} \mathrm{P}_{2} \mathrm{O}_{7}$ and (c) $\mathrm{N}_{3} \mathrm{~N}_{1} \mathrm{VP} / \mathrm{Na}_{2} \mathrm{FeP}_{2} \mathrm{O}_{7}$ cells. C-rate: $1 \mathrm{C}$. (d) Comparison of rate capability plots and (e) discharge curves at different rates for the $\mathrm{Na} / \mathrm{OE} / \mathrm{Na} 2 \mathrm{FeP} \mathrm{O}_{7}$ and $\mathrm{N}_{3} \mathrm{~N}_{1} \mathrm{VP} / \mathrm{OE} / \mathrm{Na}_{2} \mathrm{FeP} \mathrm{O}_{2} \mathrm{O}_{7}$ cells at $25^{\circ} \mathrm{C}$. C-rate: $1 \mathrm{C}-20 \mathrm{C}$. (f) Discharge curves of the $\mathrm{N}_{3} \mathrm{~N}_{1} \mathrm{VP} / \mathrm{IL} / \mathrm{Na}_{2} \mathrm{FeP}_{2} \mathrm{O}_{7}$ cell at $110{ }^{\circ} \mathrm{C}$. C-rate: $1-100 \mathrm{C}$. Voltage $(\mathrm{Na})$ and voltage $\left(\mathrm{N}_{3} \mathrm{~N}_{1} \mathrm{VP}\right)$ are the voltages of the cells with the $\mathrm{Na}$ metal and $\mathrm{N}_{3} \mathrm{~N}_{1} \mathrm{VP}$ counter electrodes, respectively (see the main text for voltage conversion). Cutoff voltage: $2.2 / 3.8 \mathrm{~V}$ for the $\mathrm{Na} / \mathrm{Na}_{2} \mathrm{FeP} \mathrm{O}_{7}$ cell and $-1.2 / 0.4 \mathrm{~V}$ for the $\mathrm{N}_{3} \mathrm{~N}_{1} \mathrm{VP} / \mathrm{Na}_{2} \mathrm{FeP}_{2} \mathrm{O}_{7}$ cell.

desodiation method preserves the morphology of the primary materials as stated above (Fig. $3 \mathrm{C}, \mathrm{i}$ ) and the rate performance with $\mathrm{OE}$ and $\mathrm{IL}$ at 25 and $90{ }^{\circ} \mathrm{C}$ (Fig. S3-S8, ESI+, includes the results of rate capability tests of the $\mathrm{Na} / \mathrm{Na}_{3} \mathrm{~V}_{2}\left(\mathrm{PO}_{4}\right)_{3}$, $\mathrm{Na} / \mathrm{NaV}_{2}\left(\mathrm{PO}_{4}\right)_{3}$, and $\mathrm{Na} / \mathrm{N}_{3} \mathrm{~N}_{1} \mathrm{VP}$ cells, and the $\mathrm{N}_{3} \mathrm{~N}_{1} \mathrm{VP} / \mathrm{N}_{3} \mathrm{~N}_{1} \mathrm{VP}$ symmetric cell with $\mathrm{OE}$ at $25^{\circ} \mathrm{C}$ and IL at 25 and $90^{\circ} \mathrm{C}$ ).

To determine the electrochemical stability of the $\mathrm{N}_{3} \mathrm{~N}_{1} \mathrm{VP}$ counter electrode, extended cycle tests accompanied by EIS measurements were performed using the $\mathrm{Na} / \mathrm{OE} / \mathrm{Na}$ and $\mathrm{N}_{3} \mathrm{~N}_{1} \mathrm{VP} / \mathrm{OE} / \mathrm{N}_{3} \mathrm{~N}_{1} \mathrm{VP}$ symmetric cells at $25{ }^{\circ} \mathrm{C}$. Cathodic and anodic polarizations for the $\mathrm{Na} / \mathrm{OE} / \mathrm{Na}$ and $\mathrm{N}_{3} \mathrm{~N}_{1} \mathrm{VP} / \mathrm{OE} / \mathrm{N}_{3} \mathrm{~N}_{1} \mathrm{VP}$ symmetric cells were cycled at $0.1 \mathrm{~mA} \mathrm{~cm}-2$, where the polarization direction was altered every $12 \min (24 \min$ for 1 cycle) (Fig. 4d). EIS was recorded in the initial state and after 10, 25, 50, 100, and 200 cycles (Fig. 4e,f). During the tests, the desertion-insertion process occurred in the $\mathrm{N}_{3} \mathrm{~N}_{1} \mathrm{VP} / \mathrm{OE} / \mathrm{N}_{3} \mathrm{~N}_{1} \mathrm{VP}$ cell, whereas $\mathrm{Na}$ metal stripping-plating process occurred in the $\mathrm{Na} / \mathrm{OE} / \mathrm{Na}$ cell. The resulting polarization profiles revealed that the two symmetric cells showed significantly different electrochemical behaviour. The $N_{3} N_{1} V P / O E / N_{3} N_{1} V P$ cell exhibited very stable cycle performance; the overpotential at the 1 st cycle was $18 \mathrm{mV}$ and did not substantially increase until the end of the measurement, providing an overpotential of 19 $\mathrm{mV}$ at the 200th cycle. Contrarily, the overpotential of the $\mathrm{Na} / \mathrm{Na}$ cell continuously increased from $23 \mathrm{mV}$ at the 1 st cycle to the end of the test (rather significantly up to $60 \mathrm{~h}$ (150 cycles)) and reached $130 \mathrm{mV}$ at the 200th cycle (Fig. 4d). This trend was confirmed by EIS measurements. The Nyquist plots for the $\mathrm{N}_{3} \mathrm{~N}_{1} \mathrm{VP} / \mathrm{N}_{3} \mathrm{~N}_{1} \mathrm{VP}$ cell were stable and roughly overlapped in all cycles (Fig. 4f). In contrast, the semicircle observed in the
$\mathrm{Na} / \mathrm{Na}$ cell kept increased and reached a width that was five times larger than that at the beginning of the measurement (Fig. $4 \mathrm{e})$. The increase in resistance corresponding to the semicircle can result from two factors. One is the dead-Na accumulation, which originates from $\mathrm{Na}$ dendrite formation because dead $\mathrm{Na}$ metal physically hinders ion transport. ${ }^{56}$ Second reason is an increase in the passivation layer on Na metal, resulting from the reaction of $\mathrm{Na}$ metal with the electrolyte. ${ }^{23,} 24$ This factor was confirmed by the time dependence of EIS for the $\mathrm{Na} / \mathrm{Na}$ and $\mathrm{N}_{3} \mathrm{~N}_{1} \mathrm{VP} / \mathrm{N}_{3} \mathrm{~N}_{1} \mathrm{VP}$ symmetric cells using OE at $25^{\circ} \mathrm{C}$ and IL at 25 and $90{ }^{\circ} \mathrm{C}$ (Fig. S9, ESI + ). The symmetric $\mathrm{N}_{3} \mathrm{~N}_{1} \mathrm{VP} / \mathrm{N}_{3} \mathrm{~N}_{1} \mathrm{VP}$ cell showed stable EIS results over $72 \mathrm{~h}$ regardless of the electrolyte and operating temperature, whereas the semicircle for the $\mathrm{Na} / \mathrm{Na}$ symmetric cells continuously increased with time in the $\mathrm{Na} / \mathrm{Na}$ symmetric cell, which agrees with the previous result by Dugas et al; 20 they reported that $\mathrm{Na}$ metal reacted with $1 \mathrm{~mol}$ $\mathrm{dm}^{-3} \mathrm{Na}\left[\mathrm{PF}_{6}\right]-\mathrm{EC} / \mathrm{DMC}$ electrolyte and forming a passivation layer, which resulted in an increase in resistance with time. ${ }^{20}$

\section{Electrochemical measurements using the $\mathrm{N}_{3} \mathrm{~N}_{1} \mathrm{VP}$ counter electrode}

The actual electrochemical measurements were carried out in a coin cell using the $\mathrm{N}_{3} \mathrm{~N}_{1} \mathrm{VP}$ counter electrode. Three well-studied positive electrode materials, $\mathrm{Na}_{2} \mathrm{FeP}_{2} \mathrm{O}_{7}$ (space group, $P \overline{1}$ ), 51 $\mathrm{Na}_{3} \mathrm{~V}_{2}\left(\mathrm{PO}_{4}\right)_{3}$ (space group, $R \overline{3} c$ ), 52 and O3-type $\mathrm{NaCrO}_{2}$ (space group $R \overline{3} m),{ }^{53}$ were selected as working electrodes. Fig. 5 shows the setup of the coin cell, charge-discharge curves, and rate capability of the $\mathrm{Na} / \mathrm{Na}_{2} \mathrm{FeP}_{2} \mathrm{O}_{7}$ and $\mathrm{N}_{3} \mathrm{~N}_{1} \mathrm{VP} / \mathrm{Na}_{2} \mathrm{FeP}_{2} \mathrm{O}_{7}$ cells with $\mathrm{OE}$ and IL at various operating temperatures (Fig. S11-S13 

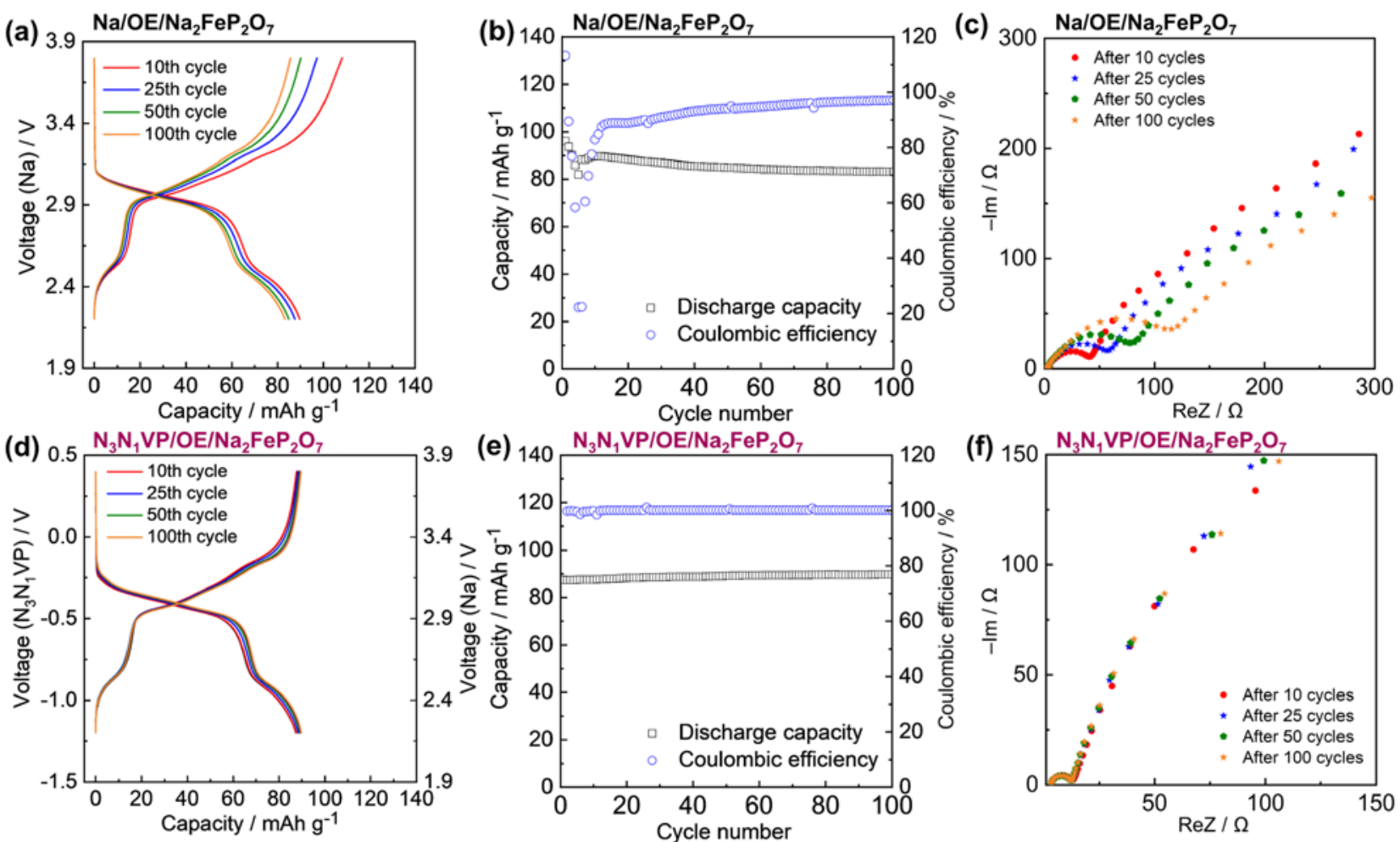

Fig. 6 Cyclability test results and the corresponding Nyquist plots based on the EIS data for the $\mathrm{Na} / \mathrm{OE} / \mathrm{Na}_{2} \mathrm{FeP}_{2} \mathrm{O}_{7}(\mathrm{a}, \mathrm{b}, \mathrm{c})$ and $\mathrm{N}_{3} \mathrm{~N}_{1} \mathrm{VP} / \mathrm{OE} / \mathrm{Na}{ }_{2} \mathrm{FeP} \mathrm{P}_{2} \mathrm{O}$ (d,e,f) cells at $25{ }^{\circ} \mathrm{C}$. Voltage $(\mathrm{Na})$ and voltage $\left(\mathrm{N}_{3} \mathrm{~N}_{1} \mathrm{VP}\right)$ are the voltages of the cell with the Na metal and $\mathrm{N}_{3} \mathrm{~N}_{1} \mathrm{VP}$ counter electrodes (see the main text for the voltage conversion). (a,d) Charge-discharge curves, (b,e) cycling plots, and (c,f) Nyquist plots. C-rate: $1 \mathrm{C}$. Cutoff voltage: $2.2 / 3.8 \mathrm{~V}$ for the $\mathrm{Na} / \mathrm{OE} / \mathrm{Na}_{2} \mathrm{FeP}_{2} \mathrm{O}_{7}$ cell and $-1.2 / 0.4 \mathrm{~V}$ for the $\mathrm{N}_{3} \mathrm{~N}_{1} \mathrm{VP} / \mathrm{OE} / \mathrm{Na}{ }_{2} \mathrm{FeP} \mathrm{O}_{7}$ cell. Frequency range: 10 $\mathrm{mHz}-100 \mathrm{kHz}$

and Fig. S14-S15 show the related data for the $\mathrm{Na}_{3} \mathrm{~V}_{2}\left(\mathrm{PO}_{4}\right)_{3}$ and $\mathrm{NaCrO}_{2}$ electrodes, respectively, $\mathrm{ESI}+$ ).

The 2032-type coin cell was assembled, as illustrated in Fig. 5a. The OE and IL were used for measurements at $25^{\circ} \mathrm{C}$, and IL was used for measurements at $90{ }^{\circ} \mathrm{C}$. Charge-discharge curves of the $\mathrm{Na} / \mathrm{Na}_{2} \mathrm{FeP}_{2} \mathrm{O}_{7}$ and $\mathrm{N}_{3} \mathrm{~N}_{1} \mathrm{VP} / \mathrm{Na}_{2} \mathrm{FeP}_{2} \mathrm{O}_{7}$ cells at $1 \mathrm{C}$ are compared in Fig. 5b,c. The right horizontal axis (ordinate; Voltage ( $\mathrm{Na})$ ) in Fig. $5 \mathrm{c}$ is the voltage converted to that of the $\mathrm{Na}$ metal standard according to the relationship: [Voltage $(\mathrm{Na})$ ] = [Voltage $\left(\mathrm{N}_{3} \mathrm{~N}_{1} \mathrm{VP}\right)$ ] - $3.4 \mathrm{~V}$. The charge-discharge curves using the $\mathrm{Na}$ metal and $\mathrm{N}_{3} \mathrm{~N}_{1} \mathrm{VP}$ counter electrodes are remarkably similar to each other at this current density. Two distinct plateaus are observed in the charge-discharge curves of $\mathrm{Na}_{2} \mathrm{FeP}_{2} \mathrm{O}_{7}$. A small plateau appears in the voltage range from 2.2 to $2.6 \mathrm{~V}$, and a sloppy plateau is observed in the voltage range from 2.6 to $3.2 \mathrm{~V}$ with Na metal counter electrode (Fig. $5 b)$. Identical shapes of curves are observed using the $\mathrm{N}_{3} \mathrm{~N}_{1} \mathrm{PV}$ counter electrode at the same voltage range from -1.2 to $0.8 \mathrm{~V}$ (corresponding to 2.2 to $2.6 \mathrm{~V}$ in Voltage $(\mathrm{Na})$ ) for a small plateau and -0.8 to $-0.2 \mathrm{~V}$ (corresponding to 2.6 to $3.2 \mathrm{~V}$ in Voltage ( $\mathrm{Na})$ ) for a flat sloppy plateau in Fig. 5c. The large overpotential and less reversible capacities are obtained at $25{ }^{\circ} \mathrm{C}$ using IL regardless of the counter electrode due to the high viscosity of 40 mol\% $\mathrm{Na}$ [FSA] salt IL (Fig. 5b,c).

Rate capability tests using the $\mathrm{Na} / \mathrm{OE} / \mathrm{Na}_{2} \mathrm{FeP}_{2} \mathrm{O}_{7}$ and $\mathrm{N}_{3} \mathrm{~N}_{1} \mathrm{VP} / \mathrm{OE} / \mathrm{Na}_{2} \mathrm{FeP}_{2} \mathrm{O}_{7}$ cells at $25^{\circ} \mathrm{C}$ clearly show the difference in electrochemical performance originating from the polarization of the counter electrodes (Fig. 5d,e). Although the discharge capacities decrease, and polarization increases as the rate increases for both cells. The $\mathrm{N}_{3} \mathrm{~N}_{1} \mathrm{VP} / \mathrm{OE} / \mathrm{Na}_{2} \mathrm{FeP}_{2} \mathrm{O}_{7}$ cell retains the discharge capacity of $63.5 \mathrm{mAh} \mathrm{g}^{-1}$ at 20C, whereas the $\mathrm{Na} / \mathrm{OE} / \mathrm{Na}_{2} \mathrm{FeP}_{2} \mathrm{O}_{7}$ cell retains the discharge capacity of 32.4 $\mathrm{mAh} \mathrm{g}^{-1}$ at $20 \mathrm{C}$. These results agree with the EIS results of the symmetric $\mathrm{Na} / \mathrm{OE} / \mathrm{Na}$ and $\mathrm{N}_{3} \mathrm{~N}_{1} \mathrm{VP} / \mathrm{OE} / \mathrm{N}_{3} \mathrm{~N}_{1} \mathrm{VP}$ cells, as discussed above (Fig. 4 e,f).

Several thermally stable ionic liquids and electrode materials have been reported for shuttle-type Na secondary battery applications, but the measurement is restricted to temperatures below $90{ }^{\circ} \mathrm{C}$ because of the melting point of $\mathrm{Na}$ metal $\left(98^{\circ} \mathrm{C}\right) .{ }^{13}$ As shown in Fig. $5 \mathrm{c}$, a comparison of the chargedischarge curves of the $\mathrm{N}_{3} \mathrm{~N}_{1} \mathrm{VP} / \mathrm{IL} / \mathrm{Na}_{2} \mathrm{FeP}_{2} \mathrm{O}_{7}$ cell at $90-110{ }^{\circ} \mathrm{C}$ confirms their nearly identical electrochemical behaviour, which indicates that the use of $\mathrm{N}_{3} \mathrm{~N}_{1} \mathrm{VP}$ counter electrode enables the measurements at temperatures above the melting point of $\mathrm{Na}$ metal. For further confirmation, the rate capability of the $\mathrm{N}_{3} \mathrm{~N}_{1} \mathrm{VP} / \mathrm{IL} / \mathrm{Na}_{2} \mathrm{FeP}_{2} \mathrm{O}_{7}$ cell was tested at $110{ }^{\circ} \mathrm{C}$; the current densities from $1 \mathrm{C}$ to $100 \mathrm{C}$ were applied every five cycles and were returned to $1 \mathrm{C}$ to examine the recuperation of the cell. (Fig. S13 shows the results for the rate performance test of the $\mathrm{N}_{3} \mathrm{~N}_{1} \mathrm{VP} / \mathrm{IL} / \mathrm{Na}_{3} \mathrm{~V}_{2}\left(\mathrm{PO}_{4}\right)_{3}$ cell at $110{ }^{\circ} \mathrm{C}$, ESI + ). The rate performance improves as temperature increases $\left(71 \mathrm{mAh} \mathrm{g}^{-1}\right.$ at $110{ }^{\circ} \mathrm{C}$ and $50 \mathrm{C}$ ), and the cell stably recuperates at $1 \mathrm{C}$ after experiencing high rates at $110^{\circ} \mathrm{C}$. Polarization increases upon the application of high current densities, but stable discharge curves are obtained at a high current density of $100 \mathrm{C}$ (Fig. 5f).

A distinct difference is observed in the results of cycle tests for the $\mathrm{Na}_{2} \mathrm{FeP}_{2} \mathrm{O}_{7}$ electrode with $\mathrm{Na}$ metal and $\mathrm{N}_{3} \mathrm{~N}_{1} \mathrm{VP}$ counter electrodes. Fig. 6 shows the results of cycle tests for the 
$\mathrm{Na} / \mathrm{OE} / \mathrm{Na}_{2} \mathrm{FeP}_{2} \mathrm{O}_{7}$ and $\mathrm{N}_{3} \mathrm{~N}_{1} \mathrm{VP} / \mathrm{OE} / \mathrm{Na}_{2} \mathrm{FeP}_{2} \mathrm{O}_{7}$ cells at $1 \mathrm{C}$ and $25^{\circ} \mathrm{C}$. The $\mathrm{Na} / \mathrm{OE} / \mathrm{Na}_{2} \mathrm{FeP}_{2} \mathrm{O}_{7}$ cell is unstable during the initial 10 cycles and suffers from the low Coulombic efficiency (91\% in average after 100 cycles) (Fig. 6b), which indicates the instability of $\mathrm{Na}$ metal counter electrode with $\mathrm{OE}$. Such behaviour was previously reported with hard carbon and $\mathrm{Na}_{3} \mathrm{~V}_{2}\left(\mathrm{PO}_{4}\right)_{3}$ with a $\mathrm{Na}$ metal counter electrode using $1 \mathrm{M} \mathrm{NaClO}_{4} \mathrm{EC} / \mathrm{PC}$ electrolyte in half-cell configuration. ${ }^{18}$ Contrarily, the $\mathrm{N}_{3} \mathrm{~N}_{1} \mathrm{VP} / \mathrm{OE} / \mathrm{Na}_{2} \mathrm{FeP}_{2} \mathrm{O}_{7}$ cell shows stable charge-discharge performance from the first cycle with a high average Coulombic efficiency of $99.9 \%$ after 100 cycles. All curves essentially overlap each other during 100 cycles (Fig. 6d). The difference in cycle performance, depending on the behaviour of the counter electrodes, is more clearly shown in the plots of discharge capacity against cycle number (Fig. $6 \mathrm{~b}, \mathrm{e}$ ). The capacity retention at the 100 th cycle is $87 \%$ for the $\mathrm{Na} / \mathrm{OE} / \mathrm{Na}_{2} \mathrm{FeP}_{2} \mathrm{O}_{7}$ cell and $102 \%$ for the $\mathrm{N}_{3} \mathrm{~N}_{1} \mathrm{VP} / \mathrm{OE} / \mathrm{Na}_{2} \mathrm{FeP}_{2} \mathrm{O}_{7}$ cell after 100 cycles. The EIS results in Fig. $6 c, f$ confirm that the interfacial resistance continuously increases for the $\mathrm{Na} / \mathrm{OE} / \mathrm{Na}_{2} \mathrm{FeP}_{2} \mathrm{O}_{7}$ cell as the cycle proceeds but does not change until the end for the $\mathrm{N}_{3} \mathrm{~N}_{1} \mathrm{VP} / \mathrm{OE} / \mathrm{Na}_{2} \mathrm{FeP}_{2} \mathrm{O}_{7}$ cell. These results imply that the $\mathrm{Na}$ metal counter electrode degrades earlier than the working electrode materials and electrolytes in the half-cell configuration, suggesting that particular attention is required to interpret the performance of new materials and electrolytes. Further cycle tests and EIS measurements were performed to validate the data using the $\mathrm{Na}_{3} \mathrm{~V}_{2}\left(\mathrm{PO}_{4}\right)_{3}$ electrode with the $\mathrm{Na}$ metal and $\mathrm{N}_{3} \mathrm{~N}_{1} \mathrm{VP}$ counter electrodes, which also confirmed the superiority of the $\mathrm{N}_{3} \mathrm{~N}_{1} \mathrm{VP}$ counter electrode to the $\mathrm{Na}$ metal counter electrode. (Fig. S16, ESIt).

Additionally, charge-discharge and rate capability tests of negative electrode materials of Hard carbon and $\mathrm{Na}_{3} \mathrm{~V}_{2}\left(\mathrm{PO}_{4}\right)_{3}$ $\left(\mathrm{V}^{3+} / \mathrm{V}^{2+}\right)$ are carried out using the $\mathrm{N}_{3} \mathrm{~N}_{1} \mathrm{VP}$ counter electrode. (Fig. S17, ESIt). As reported with the positive electrode, the $\mathrm{N}_{3} \mathrm{~N}_{1} \mathrm{VP}$ and negative electrodes showed stable chargedischarge profiles and rate performance, suggesting the stable electrochemical behavior of the $\mathrm{N}_{3} \mathrm{~N}_{1} \mathrm{VP}$ counter electrode even starting from desodiation.

\section{Conclusions}

Successful preparation of a new type of counter electrode was achieved through the synthesis of $\mathrm{NaV}_{2}\left(\mathrm{PO}_{4}\right)_{3}$ via the chemical desodiation of NASICON-type $\mathrm{Na}_{3} \mathrm{~V}_{2}\left(\mathrm{PO}_{4}\right)_{3}$ using $\mathrm{Cl}_{2}$ gas. The desodiation process using $\mathrm{Cl}_{2}$ gas preserved the morphology and electrochemical performance of the initial $\mathrm{Na}_{3} \mathrm{~V}_{2}\left(\mathrm{PO}_{4}\right)_{3}$. The $\mathrm{N}_{3} \mathrm{~N}_{1} \mathrm{VP}$ electrode, which was prepared by simply mixing $\mathrm{Na}_{3} \mathrm{~V}_{2}\left(\mathrm{PO}_{4}\right)_{3}$ and $\mathrm{NaV} \mathrm{V}_{2}\left(\mathrm{PO}_{4}\right)_{3}$, exhibited stable electrochemical behavior in both IL and $\mathrm{OE}$ electrolytes with a flat plateau at $3.4 \mathrm{~V} \mathrm{vs}$. $\mathrm{Na}^{+} / \mathrm{Na}$, indicating its high feasibility as a counter electrode in half-cell tests for sodium secondary batteries. This counter electrode provided various advantages such as facile measurements, including those at temperatures above the melting point of $\mathrm{Na}$ metal, high electrochemical stability during long cycles, low polarization, and absence of dendrite formation in comparison with Na metal counter electrode. These advantages were demonstrated through half-cell tests using the $\mathrm{Na}_{2} \mathrm{FeP}_{2} \mathrm{O}_{7}, \mathrm{Na}_{3} \mathrm{~V}_{2}\left(\mathrm{PO}_{4}\right)_{3}$, and $\mathrm{NaCrO}_{2}$ working electrodes. The half-cells with the $\mathrm{N}_{3} \mathrm{~N}_{1} \mathrm{VP}$ counter electrode exhibited stable cycles over a long period with low polarization compared to the cases with the $\mathrm{Na}$ metal counter electrode. Moreover, the electrochemical characteristics of the positive electrode materials at temperatures above the melting point of $\mathrm{Na}$ metal were confirmed using the $\mathrm{N}_{3} \mathrm{~N}_{1} \mathrm{VP}$ counter electrode. The ratio of $\mathrm{Na}_{3} \mathrm{~V}_{2}\left(\mathrm{PO}_{4}\right)_{3}$ and $\mathrm{NaV}_{2}\left(\mathrm{PO}_{4}\right)_{3}$ could be optimized depending on the target working electrode, although it was fixed as a representative value of 1:1 in this study. This new $\mathrm{N}_{3} \mathrm{~N}_{1} \mathrm{VP}$ counter electrode is an attractive means of circumventing the limitation of current Na metal counter electrode and can be used to evaluate the true performance of positive and negative electrode materials and electrolytes for sodium secondary batteries. This concept can be possibly extended to other battery systems that suffer from a lack of suitable and facile reference or counter electrode. Oxidation of electrode materials with $\mathrm{Cl}_{2}$ gas is also applicable to a variety of electrode materials, even for lithium systems. Further academic and industrial development of this methodology is expected in the future.

\section{Conflicts of interest}

There are no conflicts to declare.

\section{Acknowledgements}

This study was partly supported by the Japanese Ministry of Education, Culture, Sports, Science and Technology (MEXT) program "Elements Strategy Initiative to Form Core Research Center." J. H. is grateful to the Japan Society for the Promotion of Science (JSPS) for the Grant-in-Aid for JSPS Research Fellow.

\section{Notes and references}

Abbreviations: $\mathrm{N}_{3} \mathrm{~N}_{1} \mathrm{VP}$, in the state of $\mathrm{Na}_{3} \mathrm{~V}_{2}\left(\mathrm{PO}_{4}\right)_{3}-\mathrm{Na}_{3} \mathrm{~V}_{2}\left(\mathrm{PO}_{4}\right)_{3}$ two-phase plateau region; $\mathrm{SEI}$, solid electrolyte interphase; $\mathrm{DEC}$, dimethyl carbonate; DMC, dimethyl carbonate; $\mathrm{PC}$, propylene carbonate; NASICON, Na super ionic conductor; $C_{2} C_{1}$ im, 1-ethyl3-methylimidazolium; FSA, bis(fluorosulfonyl)amide; OE, 1 mol $\mathrm{dm}^{-3} \mathrm{Na}\left[\mathrm{PF}_{6}\right]-\mathrm{EC} / \mathrm{DMC}$ (1:1 $\left.\mathrm{vol} / \mathrm{vol}\right) ; \mathrm{IL}, 40 \mathrm{~mol} \% \mathrm{Na}[\mathrm{FSA}]-$ $\left[\mathrm{C}_{2} \mathrm{C}_{1} \mathrm{im}\right][\mathrm{FSA}]$; XRD, X-ray diffraction; SEM, scanning electron microscopy; EDS, energy dispersive $X$-ray spectroscopy; EIS, electrochemical impedance spectroscopy; CB, Super C65.

1 S.-W. Kim, D.-H. Seo, X. Ma, G. Ceder and K. Kang, Adv. Energy. Mater., 2012, 2, 710-721.

2 B. L. Ellis and L. F. Nazar, Curr. Opin. Solid State Mater. Sci., 2012, 16, 168-177.

3 M. D. Slater, D. Kim, E. Lee and C. S. Johnson, Adv. Funct. Mater., 2013, 23, 947-958.

4 N. Yabuuchi, K. Kubota, M. Dahbi and S. Komaba, Chem. Rev., 2014, 114, 11636-11682.

5 H. Kim, H. Kim, Z. Ding, M. H. Lee, K. Lim, G. Yoon and K. Kang, Adv. Energy. Mater., 2016, 6, 1600943.

6 X. Lin, M. Salari, L. M. R. Arava, P. M. Ajayan and M. W. Grinstaff, Chem. Soc. Rev., 2016, 45, 5848-5887.

7 X. Wei, X. Wang, X. Tan, Q. An and L. Mai, Adv. Funct. Mater. 2018, 28, 1804458.

8 H. Tan, D. Chen, X. Rui and Y. Yu, Adv. Funct. Mater., 2019, 29, 1808745. 
9 X. Zheng, C. Bommier, W. Luo, L. Jiang, Y. Hao and Y. Huang, Energy Storage Mater., 2019, 16, 6-23.

10 Y. Huang, L. Zhao, L. Li, M. Xie, F. Wu and R. Chen, Adv. Mater., 2019, 0, 1808393

11 J.-Y. Hwang, S.-T. Myung and Y.-K. Sun, Chem. Soc. Rev., 2017, 46, 3529-3614.

12 K. Matsumoto, J. Hwang, S. Kaushik, C.-Y. Chen and R. Hagiwara, Energy Environ. Sci., 2019, DOI: 10.1039/C9EE02041A.

13 A. Basile, M. Hilder, F. Makhlooghiazad, C. Pozo-Gonzalo, D. R. MacFarlane, P. C. Howlett and M. Forsyth, Adv. Energy Mater., 2018, 8, 1703491.

14 X. Xiang, K. Zhang and J. Chen, Adv. Mater., 2015, 27, 53435364.

15 D. I. lermakova, R. Dugas, M. R. Palacín and A. Ponrouch, J. Electrochem. Soc., 2015, 162, A7060-A7066.

16 L. Schafzahl, I. Hanzu, M. Wilkening and S. A. Freunberger, ChemSusChem, 2017, 10, 401-408.

17 J. Conder and C. Villevieille, Chem. Commun., 2019, 55, 12751278.

18 K. Pfeifer, S. Arnold, J. Becherer, C. Das, J. Maibach, H. Ehrenberg and S. Dsoke, ChemSusChem, 2019, 12, 1-9.

19 C. Bommier, D. Leonard, Z. Jian, W. F. Stickle, P. A. Greaney and X. Ji, Adv. Mater. Interfaces, 2016, 3.

20 R. Dugas, A. Ponrouch, G. Gachot, R. David, M. R. Palacin and J. M. Tarascon, J. Electrochem. Soc., 2016, 163, A2333-A2339.

21 A. Boschin, M. E. Abdelhamid and P. Johansson, ChemElectroChem, 2017, 4, 2717-2721.

22 Y. Zhang, L. Ma, L. Zhang and Z. Peng, J. Electrochem. Soc., 2016, 163, A1270-A1274.

23 T. D. Hatchard and M. N. Obrovac, J. Electrochem. Soc., 2014, 161, A1748-A1752.

24 A. Rudola, D. Aurbach and P. Balaya, Electrochem. Commun., 2014, 46, 56-59.

25 D. P. Abraham, J. R. Heaton, S.-H. Kang, D. W. Dees and A. N. Jansen, J. Electrochem. Soc., 2008, 155, A41-A47.

26 S. Yi, B. Wang, Z. Chen, R. Wang and D. Wang, RSC Advances, 2018, 8, 18597-18603.

27 D. P. Abraham, S. D. Poppen, A. N. Jansen, J. Liu and D. W. Dees, Electrochim. Acta, 2004, 49, 4763-4775.

28 N. Wongittharom, C.-H. Wang, Y.-C. Wang, C.-H. Yang and J.K. Chang, ACS Appl. Mater. Interfaces, 2014, 6, 17564-17570.

29 C.-Y. Chen, T. Kiko, T. Hosokawa, K. Matsumoto, T. Nohira and R. Hagiwara, J. Power Sources, 2016, 332, 51-59.

30 K. B. Hueso, V. Palomares, M. Armand and T. Rojo, Nano Res., 2017, 10, 4082-4114.

$31 \mathrm{~J}$. Hwang, K. Matsumoto and R. Hagiwara, Adv. Sustainable Syst., 2018, 2, 1700171.

32 J. Hwang, K. Matsumoto and R. Hagiwara, ACS Appl. Energy Mater., 2019, 2, 2818-2827.

33 X. Xia and J. R. Dahn, J. Electrochem. Soc., 2012, 159, A515A519.

34 J. Zhao, L. Zhao, N. Dimov, S. Okada and T. Nishida, J. Electrochem. Soc., 2013, 160, A3077-A3081.

35 K. Matsumoto, Y. Okamoto, T. Nohira and R. Hagiwara, J. Phys. Chem. C, 2015, 119, 7648-7655.

36 N. Yabuuchi, I. Ikeuchi, K. Kubota and S. Komaba, ACS Appl. Mater. Interfaces, 2016, 8, 32292-32299.

37 Y. Lee, H. Lim, S.-O. Kim, H.-S. Kim, K. J. Kim, K.-Y. Lee and W. Choi, J. Mater. Chem. A, 2018, 6, 20383-20392.

38 D. R. MacFarlane, N. Tachikawa, M. Forsyth, J. M. Pringle, P. C. Howlett, G. D. Elliott, J. H. Davis, M. Watanabe, P. Simon and C. A. Angell, Energy Environ. Sci., 2014, 7, 232-250.

39 Y. Xie, G.-L. Xu, H. Che, H. Wang, K. Yang, X. Yang, F. Guo, Y. Ren, Z. Chen, K. Amine and Z.-F. Ma, Chem. Mater., 2018, 30 4909-4918.

40 S. Y. Lim, H. Kim, R. A. Shakoor, Y. Jung and J. W. Choi, J. Electrochem. Soc., 2012, 159, A1393-A1397.
41 J.-S. Park, J. Kim, J. H. Jo and S.-T. Myung, J. Mater. Chem. A, 2018, 6, 16627-16637.

42 L. S. Plashnitsa, E. Kobayashi, Y. Noguchi, S. Okada and J.-i. Yamaki, J. Electrochem. Soc., 2010, 157, A536-A543.

43 K. Saravanan, C. W. Mason, A. Rudola, K. H. Wong and P. Balaya, Adv. Energy. Mater., 2013, 3, 444-450.

44 Z. Jian, C. Yuan, W. Han, X. Lu, L. Gu, X. Xi, Y.-S. Hu, H. Li, W. Chen, D. Chen, Y. Ikuhara and L. Chen, Adv. Funct. Mater., 2014, 24, 4265-4272.

45 X. Zhang, X. Rui, D. Chen, H. Tan, D. Yang, S. Huang and Y. Yu, Nanoscale, 2019, 11, 2556-2576.

46 A. Inoishi, Y. Yoshioka, L. Zhao, A. Kitajou and S. Okada, ChemElectroChem, 2017, 4, 2755-2759.

47 C. V. Manohar, T. C. Mendes, M. Kar, D. wang, C. Xiao, M Forsyth, S. Mitra and D. R. MacFarlane, Chem. Commun., 2018, 54, 3500-3503.

48 K. Matsumoto, T. Hosokawa, T. Nohira, R. Hagiwara, A Fukunaga, K. Numata, E. Itani, S. Sakai, K. Nitta and S. Inazawa, J. Power Sources, 2014, 265, 36-39.

49 A. Fukunaga, T. Nohira, Y. Kozawa, R. Hagiwara, S. Sakai, K. Nitta and S. Inazawa, J. Power Sources, 2012, 209, 52-56.

50 C.-Y. Chen, K. Matsumoto, T. Nohira, R. Hagiwara, Y. Orikasa and Y. Uchimoto, J. Power Sources, 2014, 246, 783-787.

51 T. Honma, T. Togashi, N. Ito and T. Komatsu, J. Ceram. Soc. Jpn., 2012, 120, 344-346.

52 Y. Fang, L. Xiao, X. Ai, Y. Cao and H. Yang, Adv. Mater., 2015, 27, 5895-5900.

53 C.-Y. Chen, K. Matsumoto, T. Nohira, R. Hagiwara, A. Fukunaga, S. Sakai, K. Nitta and S. Inazawa, J. Power Sources, 2013, 237, 52-57.

54 P. Atkins, J. d. Paula and J. Keeler, Atkins' Physical Chemistry 11th Edn., Oxford University Press, 2017.

55 J. Gopalakrishnan and K. K. Rangan, Chem. Mater., 1992, 4, 745-747.

56 K.-H. Chen, K. N. Wood, E. Kazyak, W. S. LePage, A. L. Davis, A J. Sanchez and N. P. Dasgupta, J. Mater. Chem. A, 2017, 5 11671-11681. 
